\title{
Victims as a Third Party: Empowerment of Victims?
}

\author{
Liesbeth Zegveld \\ Professor of War Reparations, University of Amsterdam; lawyer, \\ Prakken d'Oliveira Human Rights Lawyers, Amsterdam, The Netherlands
}

\begin{abstract}
This article examines whether victims can claim rights of their own before international criminal courts. These courts remain divided on the role of victims. Even when they allow victims to participate and claim reparation, it is a restricted participation. Before the ICC victims have a third-party role, being merely additional to the procedure. What's more victims are treated collectively. They are assigned a collective representative, their right to choose legal counsel thus not being an absolute right. Due to the high number of victims and with an apparent wish to bring as many victims as possible in the procedure, also reparations are granted collectively. Reparations are provided to victims and communities even if they have not applied for reparations, setting aside individual claims. The result is that victims are the target of reparation, they are treated as objects rather than subjects who can demand a remedy.
\end{abstract}

\section{Keywords}

victims - reparations - international criminal courts - participation - collective claims

One day before the trial against the former president of Ivory Coast, Gbagbo, started at the International Criminal Court, in January 2016, the prosecutor Fatou Bensouda told journalists 'that the purpose of the trial [...] is to uncover

* The author is grateful to Nataša Nedeski for her contribution to this article.

(C) L. ZEGVELD, 2018 | DOI:10.1163/15718123-01806002

This is an open access article distributed under the terms of the prevailing CC-BY-NC license at the time of publication. 
the truth through purely a legal process $[\ldots]$, for the sake of doing justice for the victims.'1

Victims are a key reason for international criminal trials. Trials are said to be held because of the great numbers of victims the crimes have caused. Perpetrators are prosecuted so victims can see justice being done, ${ }^{2}$ and of course the prosecution of perpetrators is in and of itself valuable to victims. Yet, international criminal trials seem to be lacking when it comes to a key aspect of doing justice: accommodating victims who want to claim their own rights before international criminal courts. In addition to their interest in seeing perpetrators tried and punished, victims also have different interests, interests of their own. For one thing: they have suffered damage. Are international criminal courts the right place of action to meet these interests?

The International Criminal Court (ICC) is generally described as victimfriendly or victim-centred, ${ }^{3}$ particularly when compared to the ad hoc tribunals that preceded it. ${ }^{4}$ Under the Rome Statute of the ICC, doing justice was conceived to cover not only the prosecution and punishment of perpetrators of international crimes, but to also cover the provision of justice to victims through participation and reparations. ${ }^{5}$ However, this article demonstrates that the ICC's approach to victims in practice does not appear to do justice to the fact that victims seek recognition of their individual suffering and are legally entitled to reparations, in their own right, for the damage they have suffered.

1 ICC, OTP, ICC Prosecutor's statement at press conference, ahead of the trial-start of the Prosecution's case against Messrs. Laurent Gbagbo and Charles Blé Goudé, Press Release of 27 January 2016, <www.icc-cpi.int/Pages/item.aspx?name=otp-stat-27-01-2016 $>$, accessed 22 December 2017.

2 See also the Preamble of the ICC statute: 'Mindful that during this century millions of children, women and men have been victims of unimaginable atrocities that deeply shock the conscience of humanity'.

3 L. Moffett, 'Reparations for Victims at the International Criminal Court: A New Way Forward?', 21 The International Journal of Human Rights (2017) 1204-1222, p. 1205; C. van den Wyngaert, 'Victims before International Criminal Courts: Some Views and Concerns of an ICC Trial Judge', 44 Case Western Reserve Journal of International Law (2011) 475-496, p. 479.

4 M. Henzelin et al., 'Reparations to Victims before the International Criminal Court: Lessons from International Mass Claims Processes', 17 Criminal Law Forum (2006) 317-344, p. 318; L. Catani, 'Victims at the International Criminal Court: Lessons Learned from the Lubanga Case', 10 Journal of International Criminal Justice (2012) 905-922, p. 921.

5 L. Moffett, 'Elaborating Justice for Victims at the International Criminal Court: Beyond Rhetoric and the Hague', 13 Journal of International Criminal Justice (2015) 281-331, p. 283. 
The article begins by discussing how international criminal courts in general have struggled with their approach to the role of victims in criminal proceedings (Section 2). There has been outright opposition to victims' participation in international criminal trials, reluctant acceptance, and only apparent embracement. At first sight, some international criminal courts today appear to have embraced the role of victims in their proceedings, but under the surface victims struggle to get their individual suffering and damage recognized.

This struggle of victims in international criminal trials is subsequently illustrated by focusing on the ICC. It is argued that the ICC's approach to victims seeking reparations in fact impedes the full recognition and empowerment of individual victims, and - much like the ad hoc tribunals that preceded it continues to treat victims as objects rather than subjects.

For this purpose, three aspects of the ICC's approach to victims seeking reparation are highlighted. First, victims seeking reparations are merely third parties in ICC proceedings (Section 3). As third parties they do not determine the charges, with the result that the charges may not fit (all of) the damage they have personally suffered. Victims' participation is fully dependent upon the discretion of the Court, and the Court can even make a reparations order without hearing the views of those that have suffered damage.

What is more, the ICC tends to deal with victims collectively, denying them the individual attention their claims may need (Section 4). This collective approach manifests itself in the practice of appointing a collective legal representative for groups of victims, as well as in the practice of awarding collective reparations. To make matters worse, rather than applying the legal principle of accountability to victims' claims for damage, the ICC has a tendency to address victims' damage as a humanitarian problem that can be solved through humanitarian assistance (Section 5).

For a long time, victims did not play any role in international criminal tribunals. Victims were virtually absent from the trials before the Nuremberg International Military Tribunal (IMT) between 20 November 1945 and 1 October 1946. Hardly any victims were called to testify, let alone allowed to join as civil parties to receive reparation. Various reasons have been given for victims' exclusion from the Nuremberg trials. One is that the Nuremberg trials were dominated by American prosecutors, acting in the Anglo-American common 
law tradition. ${ }^{6}$ Common law countries generally do not provide for victim participation and compensation in connection with criminal cases, and any compensation claim must be pursued via a civil lawsuit.

After the Nuremberg trials, small steps were taken towards accommodating victims in international criminal trials. In 1948, a provision on reparation for victims of genocide was included in a draft of the Genocide Convention, ${ }^{7}$ but was left out of the final text of the Convention. ${ }^{8}$ It was believed that redress and compensation of victims should be part of the jurisdiction of a future Genocide Court, ${ }^{9}$ which would be 'authorized to assess damages on behalf of persons found to have sustained losses or injuries as a result of the violation of this Convention by any High Contracting Party'.10 As we know, this Genocide Court never saw the light of day.

The establishment of a permanent criminal tribunal then became one of the projects of the International Law Commission (ILC). ${ }^{11}$ Yet, the ILC eventually decided to delete from its 1994 draft statute an article on reparations, on the basis of the argument that an international criminal court would not be an appropriate forum for ordering reparations. ${ }^{12}$

6 Another reason is that at the time of the IMT 'there was a general lack of awareness/or disbelief of the full extent of the Nazi crimes, including the holocaust'. See S.B. Garkawe, 'The Role and Rights of Victims at the Nuremberg International Military Tribunal', in H.R. Reginbogin, C.J.M. Safferling and W.R. Hippel (eds.), Die Nürnberg Prozesse: Völkerstrafrecht seit 1945: Internationale Konferenz zum 6o Jahrestag (KG Saur, Munich, 2006) 86-93.

7 Convention on the Prevention and Punishment of the Crime of Genocide (adopted 9 December 1948, entered into force 12 January 1951); W.A. Schabas, Genocide in International Law: The Crime of Crimes ( $1^{\text {st }}$ edn, Cambridge University Press, Cambridge, 2000), p. 400; Ecosoc, Draft Convention on the Crime of Genocide (E/447, $\left.5^{-13}\right)$, Art. XIII. The draft article read: 'When genocide is committed in a country by the government in power or by sections of the population, and if the government fails to resist it successfully, the State shall grant to the survivors of the human group that is a victim of genocide redress of a nature and in an amount to be determined by the United Nations'.

8 Schabas, supra note 7, p. 400.

$9 \quad$ Ibid:; Article 6 of the Convention on the Prevention and Punishment of the Crime of Genocide calls for criminals to be tried 'by such international penal tribunals as may have jurisdiction'.

Ecosoc, Draft Convention, Communications Received by the Secretary-General, (A/401), Art. VII (as cited in H. Abtahi and P. Webb, The Genocide Convention: The Travaux Préparatoires (Martinus Nijhoff, Leiden, 2009), p. 380).

11 See UngA, Prevention and Punishment of the Crime of Genocide (A/RES/3/260).

12 Article 47 of the Draft Statute for an International Criminal Court 22 July 1994. See ILC, Report of the International Law Commission on the work of its forty-sixth session, p. 6o, paras. 
In line with the ILC's view, the International Criminal Tribunal for the Former Yugoslavia (ІСТY ${ }^{13}$ and the International Criminal Tribunal for Rwanda (ICTR ), ${ }^{14}$ the first international criminal tribunals after 1948, lack jurisdiction to deal with compensation for victims. The victims of crimes within the jurisdiction ratione materiae of these tribunals have no role in their own right before these tribunals. They only serve as witnesses and cannot claim compensation from those convicted of genocide. ${ }^{15}$ It has been considered that the approach of these tribunals reduces victims to mere objects of international criminal proceedings rather than subjects with any rights to present their own interests. ${ }^{16}$

Nevertheless, the basic principle that victims have rights was recognized when the ICTY and ICTR were instituted. In its Resolution 827 (1993) of 25 May 1993 adopting the Statute of the International Criminal Tribunal for the former Yugoslavia, the Security Council decided that 'the work of the International Tribunal shall be carried out without prejudice to the right of victims to seek, through appropriate means, compensation for damages incurred as a result of violations of international humanitarian law'.17 The idea was that they turn to domestic courts. Rule 106 of the Rules of both Tribunals stipulates that victims seeking compensation must apply to a national court or other competent body. In these domestic proceedings, the victims may avail themselves of judgments of the ICTY or ICTR. ${ }^{18}$

3-4, <http://legal.un.org/ilc/texts/instruments/english/commentaries/7_4_1994.pdf>, accessed 20 December 2017. For the 1993 draft, see UNGA, Report of the International Law Commission on the work of its forty-fifth session (A/48/10), Art. 53(4).

13 UNSC, Resolution 808 (s/REs/808), para. 1.

14 UNSC, Resolution 955 (s/RES/955), para. 1.

15 UNSC, Resolution 827 (s/RES/827). Both the ICTY and ICTR Statutes and Rules provide for the restitution of property or the proceeds thereof to victims, and in this context a Trial Chamber may determine the rightful owner of the property at issue. Thus, there is a mechanism in place which provides a remedy for minor crimes. However, for more serious forms of damage - harm to life or person - there is no remedy under the said Statutes. Indeed, Rule 106 of the Rules of both Tribunals stipulates that victims seeking compensation must apply to a national court or other competent body. In these domestic proceedings, the victims may avail themselves of judgments of the ICTY or ICTR. See L. Zegveld, 'Remedies for victims of violations of international humanitarian law', 85(851) International Review of the Red Cross (2003) 523.

16 C. Jorda and J. de Hemptinne, 'The Status and Role of the Victim', in: A. Cassese et al. (eds), The Rome Statute of the International Criminal Court: A Commentary (oup, Oxford, 2002) 1387-1419, p. 1389; Moffett, supra note 5, p. 283.

17 UNSC Resolution 827 (s/REs/827), para. 7 .

18 Zegveld, supra note 15, p. 523 . 
Moreover, both the ICTY and ICTR have at some point considered revisions to their Statutes to incorporate victims' right to compensation..$^{19}$ However, the possibility of amending the Statute and Rules to this end was eventually rejected by both the ICTY and ICTR. This rejection was grounded in fear for a resultant additional workload and a significant impact on the conduct of the proceedings and the length of the trials.

The judges of the ICTY and ICTR argued that the Tribunals' aim had consistently been to minimize the length of preventive detention, which is a fundamental right of the accused, by shortening trials. It would, in their view, not be wise to implement a new system which would counter these efforts. Expanding the ICTR's mandate with compensation claims would in the ICTR's view 'not be efficacious, would severely hamper the everyday work of the Tribunal and would be highly destructive to the principal mandate of the Tribunal', ${ }^{20}$

It was for this reason that the ICTY proposed that a mechanism, modelled on that of an international mass claim procedure, should be created. In its view, this would be a much faster way to ensure that the rights of the victims of the conflict in the former Yugoslavia are satisfied. It would also be fairer as it would, theoretically, cover all victims. ${ }^{21}$

19 UNSC, Letter dated 2 November 2000 from the Secretary-General addressed to the President of the Security Council (S/200o/1063), annex 'Letter dated 12 October 2000 from the President of the International Tribunal for the Former Yugoslavia addressed to the SecretaryGeneral' (ICTY), Appendix 'Victims' compensation and participation'; UnSC, Letter dated 14 December 2000 from the Secretary-General addressed to the President of the Security Council (s/200o/1198), annex 'Letter dated 9 November 2000 from the President of the International Criminal Tribunal for Rwanda addressed to the Secretary-General' (ICTR). In the letters addressed to the Secretary-General, the Tribunals addressed the question whether compensation for victims of crimes under their jurisdiction should be the responsibility of the Tribunals. The judges conclude that victims have a right to compensation. In the letter from the President of the ICTR, ' $t$ t] he judges wholeheartedly empathize with the principle of compensation for victims, but, for the reasons set out below, believe that the responsibility for processing and assessing claims for such compensation should not rest with the Tribunal'; see also Unsc, Appendix 'Victims' compensation and participation' (s/200o/1063) (ICTY), para. 46.

20 UNSC, annex S/2000/1198 (ICTR), supra note 19, para. 4. The reasons against amending the ICTR Statute to cover compensation for victims are similar to those expressed by the ICTY. Ibid., para. 12 reads: 'The work of the Tribunal has been considerably complicated by the uniqueness of its mandate, the ground-breaking nature of its considerations, the necessity of developing new models of criminal procedure and the development of new organizational structures'. and ICTR have called upon the Security Council to establish a compensation scheme 
While the ICTY and Iст R believed that compensation claims should not be dealt with by them, remarkably they did advocate for a victims' compensation scheme to be adopted by the International Criminal Court. ${ }^{22}$ And they did so successfully: in contrast to the ICTY and ICTR, the ICC may award reparations to the benefit of individual victims. ${ }^{23}$ It may do so directly against a convicted person. ${ }^{24}$ Interestingly, the concerns expressed by the ICTY and ICTR, such as the fear that criminal trials would be seriously delayed, were apparently not considered prohibitive by the drafters of the Rome Statute. The International

for victims of the Yugoslav conflict and the Rwanda genocide, which would be quicker and simpler. The ICTY proposed that a mechanism modelled on that of an international compensation commission, could be created; UNSC, annex S/2000/1198 (ICTR) supra note 19, para. 15. The ICTR proposed that victims' claims may be assessed and processed by a specialized agency set up by the United Nations, or some other agency to administer a compensation scheme or trust fund that can be based upon individual application, or community need or some group-based qualification. The ICTR could be involved in this by empowering it to order payments from a trust fund for victims actually appearing before it as witnesses in a case. These proposals have not produced any results.

ICTR, Paper by Elsie Effange-Mbella (Gender Adviser, Office of the Registrar, ICTR) on Support Measures to Victims and Witnesses Summoned to Appear before the Tribunal (ICTR Conference on Challenging Impunity, 7-9 November 2006), para. 27, available at $<\mathrm{http}: / /$ ictr-archiveog.library.cornell.edu/ENGLISH/challenging_impunity/support_measures .pdf $>$, accessed 21 December 2017.

23 Art 75(1) Rome Statute of the International Criminal Court (adopted 17 July 1998, entered into force 1 July 2002) (hereafter ICCSt.); See on reparation claims before the ICC: J.B. Jeangène Vilmer, Réparer L'irréparable: Les réparations aux victimes devant la Cour pénale internationale (Presses Universitaires de France, Paris, 2009).

24 Art. 75(2) ICCSt; Reparation may take the form of restitution, compensation and rehabilitation, Art. 75(1) ICCSt.; The ICC can act on an application of a victim or exceptionally on its own motion. Where the Court acts on its own initiative, notice will be given to the relevant accused as well as to the victims and other interested parties. See Rule 95(1) Rules of Procedure and Evidence, adopted by the First Session of the Assembly of States Parties, 9 September 2002, Official Records ICC - ASP /1/3 (hereafter ICC RPE); The Court's competence to act on its own motion, envisages to address possible inability of victims to participate due to geographical distance or lack of financial means. See UnSC, appendix S/2000/1063 (ICTY) supra note 19, paras. 16-17; D. Donat-Cattin, 'Reparations to victims', in O. Triffterer and K. Ambos (eds.), Commentary on the Rome Statute of the International Criminal Court: Observers' Note, Article by Article (Hart Publishing, Oxford, 1999), p. 967; See Muttukumaru, 'Reparations to victims', in R.S. Lee (ed.), The International Criminal Court: The Making of the Rome Statute, Issues, Negotiations, Results (Kluwer Law International, The Hague, 1999), p. 262. The reparation proceedings take place after the person prosecuted has been declared guilty of the alleged facts. 
Criminal Court is established with similar goals in mind as the ICTY and ICTR, i.e. the prosecution and trial of suspects of international crimes.

The Rome Statute of the ICC is the first embodiment of the right of victims to reparations in international criminal proceedings. ${ }^{25}$ Moreover, the Rome Statute provides for the possibility of victim participation in ICC proceedings. ${ }^{26}$

As for other international criminal courts currently operative, the picture is mixed. Victims can take part in the criminal proceedings before the Extraordinary Chambers in the Courts of Cambodia (ECCC) and claim reparation provided they are a victim of a crime within the jurisdiction of the Court. ${ }^{27}$ The Special Tribunal for Lebanon does not decide upon reparation claims itself but 'may identify victims who have suffered harm as a result of the commission of crimes by an accused convicted by the Tribunal. ${ }^{28}$ Subsequently, when the Tribunal has found the accused guilty, a victim may bring an action in a Lebanese or other national court or other competent body to obtain compensation, based on the judgment of the Lebanon Tribunal which shall be final and binding as to the criminal responsibility of the convicted person. ${ }^{29}$

25 See Article 75 ICCSt.

26 See Article 68 ICCSt.

27 The Extraordinary Chambers are regular Cambodian courts with international features, in particular in terms of the composition and applicable law. The Eccc's Statute and Rules of Procedure combine domestic and international law. See Article 33 (new), Law on the Establishment of Extraordinary Chambers in the Courts of Cambodia for the Persecution of Crimes Committed During the Period of Democratic Kampuchea (27 October 2004) (NS/RKM/1004/oo6) (hereafter the EcCC Law); Art. 12, Agreement Between the United Nations and the Royal Government of Cambodia Concerning the Prosecution Under Cambodian Law of Crimes Committed During the Period of Democratic Kampuchea (2003) (hereafter the EccC Agreement). Neither EccC Law nor EccC contain provisions in respect of reparation, but the Internal Rules of the Extraordinary Chambers, which are in turn based on the Cambodian Criminal Code that also provides for victims' reparation and relevant international standards. See rules 23, 100(2), 110(3) and 113(1) of the Internal Rules of Extraordinary Chambers in the Courts of Cambodia (Rev. 3), as revised on 6 March 2009 (hereafter EccC Internal Rules). The legal possibilities for victims to obtain reparation in the ECCC reflects the openness of Cambodian law, which follows the French model of criminal procedure, to victims' involvement in criminal cases.

28 UNSC, Resolution 1757 (s/RES/1757), Attachment 'Statute of the Special Tribunal for Lebanon' (hereafter STLSt.), Article 25.

29 Art. 17 STLSt. provides that victims may present their views and concerns under certain conditions. 
The remaining international or internationalized criminal courts are silent on victims' reparations matters or rely on domestic courts, referring to national courts in their statutes as the fora where victims can present their claims after successful convictions at the international level..$^{30}$

All in all, the picture painted is not one of sheer conviction and belief in victims' empowerment within international criminal courts. Some international

$30 \quad$ E.g, Rule 105 of the Rules of Procedure and Evidence of the Special Court for Sierra Leone, as amended at Sixth Plenary, 14 May 2005 stipulates: 'The Registrar shall transmit to the competent authorities of the States concerned the judgment finding the accused guilty of a crime which has caused injury to a victim. Pursuant to the relevant national legislation, a victim or persons claiming through him may bring an action in a national court or other competent body to obtain compensation. For the purposes of a claim made under Sub-Rule (B) the judgment of the Special Court shall be final and binding as to the criminal responsibility of the convicted person for such injury'. The successor of the ICTY and ICTR, UNMICT, follows its predecessors. Rules of Procedure and Evidence (26 September 2016) (MICT/1/Rev.2), Rule 130 reads 'The Registrar shall transmit to the competent authorities of the States concerned the judgement finding the accused guilty of a crime which has caused injury to a victim. (B) Pursuant to the relevant national legislation, a victim or persons claiming through the victim may bring an action in a national court or other competent body to obtain compensation. (C) For the purposes of a claim made under paragraph (B) the judgement of the Mechanism shall be final and binding as to the criminal responsibility of the convicted person for such injury'. There are mixed tribunals that refused to order or address compensation claims in practice, even though it was possible. E.g., Specialist Panels of the Dili District Court. UnTAET, Regulation 2000/15 (UNTAET/REG/200o/15), Section 25 provided the establishment of a Trust Fund. Regulation 2001/25 (UNTAET/REG/2001/25), Section 50(1) refers compensation claims to competent courts, whereas Section $50(2)$ opted the Panel with the possible reparations order. However, the Trust Fund was deleted in the amended directives and the Panel never ordered reparation claims. See also S. Linton, Putting Things into Perspective: The Realities of Accountability in East Timor, Indonesia and Cambodia, Maryland Series in Contemporary Asian Studies (University of Maryland School of Law, Baltimore, MD, 2005), pp. 1, 72, 76. The War Crimes Chamber of the Court of Bosnia and Herzegovina. Art. 198(2) of The Criminal Procedure Code Official Gazette of BiH, no. 36/2003 (21 December 2003) states '[i]n a verdict pronouncing the accused guilty, the Court may award the injured party the entire claim under property law or may award him part of the claim under property law and refer him to a civil action for the remainder. If the data of criminal proceedings do not provide a reliable basis for either a complete or partial award, the Court shall instruct the injured party that he may take civil action to pursue his entire claim under property law'. However, the War Crimes Chamber refrained from ordering reparations. Quoted in osce, Mission to BiH, Fourth Report in the Case of Željko Mejakic and Others, June 2007, pp. 3-4 (as cited in B. Ivanišević, The War Crimes Chamber in Bosnia and Herzegovina: From Hybrid to Domestic Court (International Center for Transitional Justice, New York, 2008) pp. 20-21). 
criminal fora have recognized victims' rights and sometimes also offer private causes of action to individual victims. However, these courts are still few in number. Most international criminal courts still deny access to victims or (partly) refer them to domestic courts.

The focus of this article will now turn to the ICC, one of the few international criminal courts that does provide access to victims. Due to the possibilities the Rome Statute offers victims in terms of victim participation and seeking reparations, the ICC is generally described as 'victim-friendly' or 'victim-centred'. ${ }^{31}$ Indeed, when compared to the ad hoc tribunals that preceded it, the ICC's accommodation of victims is a serious advance. ${ }^{32}$

Nevertheless, the way in which the ICC deals with victims in practice continues the trend of disempowering victims and treating them as objects rather than subjects who can demand a remedy for the damage they have personally suffered. Victims are mere third-parties in the criminal procedure, their influence on the procedure is limited. Further these courts take a collective approach to victims in which the individual characteristics of their claims can become lost. What is more, the approach to victims' claims to reparations exposes a tension between humanitarian assistance and legal reparation. The ultimate consequence of this approach is that there is only a weak relation between the claim(s) for reparations and the legal accountability of the convicted person towards one or more victims.

The Third-party Role of Victims Seeking Reparations

A first problem encountered by victims aiming to claim rights of their own before the ICC is the issue of their third-party role. Victims can be afforded the right to participate in proceedings but are additional to the criminal procedure. They cannot initiate a procedure nor can they terminate it. They also do not determine the charges, which means that they can never in a true sense claim their damage. The charges are not their own but rather are determined by the Prosecutor, often burdened by political choices. Consequently, the eligibility of a particular victim's damage for reparations depends upon the Prosecutor's selection of charges, ${ }^{33}$ and the charges may not (entirely) fit the damage of victims. In the Lubanga case, for example, civilians targeted by Lubanga's troops

\footnotetext{
31 Moffett, supra note 3, p. 1205; Van den Wyngaert, supra note 3, p. 479.

32 Henzelin et al., supra note 4, p. 318; Catani, supra note 4, p. 921.

33 Moffett, supra note 3, p. 1207.
} 
could not officially be recognized as victims because the warlord was only convicted of enlisting and using child soldiers. ${ }^{34}$

The Rome Statute offers the possibility for victims to express their views and concerns during criminal proceedings, as well as the possibility of victim participation before the Court issues a reparations order. However, both possibilities of victim participation are limited and dependent upon the Court's discretion: a direct manifestation of victims' third-party role.

During the criminal trial, victims can only participate to the extent they are allowed to by the Court. Whether the Court will allow them present their views and concerns depends on whether victims succeed in convincing the Court that their interests are at stake and that they are linked to the legal issue or evidence at hand. ${ }^{35}$ The Court takes a separate decision on the question of 'interests' before it allows victims to participate. ${ }^{36}$ Personal interests recognized by the Court are not limited to issues on reparation, ${ }^{37}$ but neither is it sufficient to have a general interest in the outcome of the case.

It is significant in this regard that the Statute speaks of 'interests' instead of rights. The use of the word rights is reserved for the rights of the accused. ${ }^{38}$ Victims cannot invoke any rights under the Statute as the Statute does not afford them any rights. ${ }^{39}$

If the Court decides that their interests are indeed at stake, it is for the Court to determine at which stage victims may present their views and concerns.

34 Prosecutor v. Lubanga (Judgment on the appeals against the 'Decision establishing the principles and procedures to be applied to reparations' of 7 August 2012), 3 March 2015, International Criminal Court, ICC-01/04-01/o6 (hereafter Lubanga (Appeals Judgment on Reparations principles)), para. 186.

35 Art. 68(3) ICCSt. states: 'Where the personal interests of the victims are affected, this Court shall permit their views and concerns to be presented and considered at stages of the proceedings determined to be appropriate by the Court'.

36 Rule 89(1) ICC RPE mentions opening and closing statements.

37 Prosecutor v. Lubanga (Decision on Victims' Participation), 21 January 2008, International Criminal Court, ICC-01/04-01/o6 (hereafter Lubanga (Victims' Participation)), para. 98.

38 E.g., Art. 64(2) ICCSt: 'The Trial Chamber shall ensure that a trial is fair and expeditious and is conducted with full respect for the rights of the accused and due regard for the protection of victims and witnesses'; Art. 75(6) ICCSt recognises that victims have rights but not in relation to the court proceedings: 'Nothing in this article shall be interpreted as prejudicing the rights of victims under national or international law'.

39 The only provision referring to 'rights of victims' is Rule 97(3) ICC RPE stipulating: 'In all cases, the Court shall respect the rights of victims and the convicted person'. But as nowhere else in the Statute victims' rights are mentioned, it is not clear which rights this Rule refers to. 
Article 68 ICC Statute stipulates that the intervention of victims must be conducted in a way 'which is not prejudicial to or inconsistent with the rights of the accused and a fair and impartial trial'. Whether the Court will allow victims to participate will therefore depend on the case at hand and its developments in court. If the criminal trial takes more time than anticipated the time left for victims will be cut. Similarly, in case of a large number of victims their time to present their views and concerns will also be reduced. The bottom line is that when and how the victims can present their views and concerns is dependent on the discretionary powers of the relevant Chamber. While views and concerns may be allowed during the criminal proceedings, victims' reparations claims are dealt with after the criminal proceedings. Even though one would assume that at this stage there is no risk of victim participation interfering with the criminal trial, victims' participation at this stage is also limited.

Article 75(3) of the ICC Statute provides that

[b] efore making an [reparation] order under this article, the Court may invite and shall take account of representations from or on behalf of the convicted person, victims, other interested persons or interested States (emphasis added).

Apparently, the Court can make an order for reparation without hearing the views of those who have suffered the damage. If the victims or their representatives do not present their views on reparation themselves, the Court can invite them to present their views, but is not obliged to do so.

This is even more remarkable if we realise that the Court has the power to make a (collective) reparations order on its own motion, in which case the victims have no active role at all and are truly mere objects of the proceedings.

It is true that victims can object to receiving reparation because, as stated by the Court in the Lubanga case, 'reparations are entirely voluntary':

The Appeals Chamber notes that, despite correctly recognising the voluntary nature of victims' participation in the reparation programmes, the Trial Chamber made their participation in such programmes dependent on whether the Trust Fund 'considers it appropriate'. The Appeals Chamber notes that, at the time of making applications for reparations, the victims either applied for individual awards or applied for a collective award, without knowledge of the kind of a collective programme that would be ultimately adopted. The Appeals Chamber therefore finds that it is necessary to seek the victims' consent when a collective award is 
made, consistent with the principle, identified by the Trial Chamber, that ' $[r]$ eparations are entirely voluntary' 40

But the words 'entirely voluntary' are strange words in a court of law, where legal disputes, between parties, are handled. It reveals a view of victims as recipients rather than as participants submitting a claim. They are not acting out of their own initiative, they are not demanding anything, but are offered something that they can refuse. Using this approach, victims are reduced to wounded, injured persons who have suffered damages, rather than a party submitting a claim that a court needs to adjudicate.

Also striking is the order of the respective representations mentioned in Article 75(3) ICC Statute, which refers to 'the convicted person, victims, other interested persons or interested States'. Strangely, this provision on victims' reparations mentions victims only after it mentions the convicted person. As it is their reparation claim one would expect the victims to be the first to be invited by the Court to present their claim.

In sum, the role of victims as mere third parties in the proceedings at the ICC has severe implications for their participation in the trial. They have no rights, only interests. Whether and, if so, how they are allowed to participate is entirely in the hands of the Court. The ICC can make an order for reparation without hearing the views of those that have suffered damage, and can even make a reparations order on its own motion; without any active role of victims. This approach indicates that the Court is still a long way from treating victims as subjects who can demand a remedy for the damage they have personally suffered and, as further discussed in the next section, this is only exacerbated by the Court's collective approach to victims.

\section{4} A Collective Approach to Victims

In addition to being mere third parties in the criminal proceedings, victims are dealt with collectively. They are generally represented collectively before the ICC and the Court may (and often does) award collective reparations.

$40 \quad$ Lubanga (Appeals Judgment on Reparations principles), supra note 34, para. 16o, citing Prosecutorv. Lubanga (Decision establishing the principles and procedures to be applied to reparations), 7 August 2012, International Criminal Court, ICC-01/04-01/06 (hereafter Lubanga (Decision on Reparation principles)), para. 204. 


\subsection{The Collective Legal Representative}

An important aspect of the ICC's collective approach to victims is their representation, which is often handled collectively. A legal representative can be an important tool for victims, enabling them to have their voices heard in ICC proceedings. ${ }^{41}$ Once victims have been granted the right to participate, they have the possibility to present their views with or without counsel. Article 68(3) ICC Statute does not require victims to have a legal representative, but having a legal representative does bring with it certain advantages. It follows from rule 91 of the ICC's Rules of Procedure and Evidence, that victims who have a legal representative will have more opportunities to participate during proceedings ${ }^{42}$ than victims who choose not to be represented. In accordance with rule 89(1), both victims with and without a legal representative may make opening and closing statements if the Chamber finds it appropriate. ${ }^{43}$

Rule 9o provides that 'a victim shall be free to choose a legal representative'. In practice, however, this freedom has turned out to be an empty shell. That same rule go stipulates: 'Where there are a number of victims the Chamber may, for the purposes of ensuring the effectiveness of the proceedings, request the victims or particular groups of victims, if necessary with the assistance of the Registry, to choose a common legal representative or representatives. ${ }^{4}$ This provision has led to the practice of the Registry or Chambers appointing a collective representative for large groups of victims. ${ }^{45}$ While victims generally bring their own legal representatives when they apply for participation, the individual legal counsel of victims will be excused when the Court has appointed a collective legal representative. ${ }^{46}$

41 D. Suprun, 'Legal Representation of Victims before the ICC: Developments, Challenges and Perspectives', 16 International Criminal Law Review (2016), 972-994.

42 For example, attending and participating during hearings and the possibility to question a witness, ex rule 9o paragraphs 1-2 ICC RPE.

43 Prosecutor v. Kony, Otti, Odhiambo, Lukwiya and Ongwen (Decision on legal representation, appointment of counsel for the defence, protective measures and time-limit for submission of observations on applications for participation a/oo1o/o6, a/oo64/o6 to a/0070/06, a/0081/06 to a/0104/06 and a/0111/o6 to a/0127/o6), 1 February 2007, International Criminal Court, ICC-02/04-01/05, paras. 2-12.

44 Rule 9o(2) ICC RPE.

45 See Human Rights Watch, Who Will Stand for Us? Victims' Legal Representation at the Icc in the Ongwen Case and Beyond (Human Rights Watch, 2017).

46 Prosecutor v. Ruto, Kosgey and Sang (Decision on Victims' Participation at the Confirmation of Charges Hearing and in the Related Proceedings), 8 August 2011, International Criminal Court, ICC-01/o9-01/11, paras. 67, 77; Prosecutor v. Muthaura, Kenyatta and 
The Court has repeatedly stated that the right to choose legal counsel is not an absolute right and that it is subjected to paragraph 2 and 3 of rule 90 of the Rules of Procedure and Evidence. ${ }^{47}$ Even though victims themselves should have the opportunity to decide on a collective legal representative with the help of the Registry, ${ }^{48}$ the Court has regularly invoked regulation 8o(1) of the Regulations of the Court, which provides that a Chamber, following consultation with the Registrar, may appoint a legal representative of victims where the interests of justice so require. ${ }^{49}$ In invoking regulation 80 the Court has increasingly given weight to considerations of cost and efficiency, and has

Hussein Ali (Decision on Victims' Participation at the Confirmation of Charges Hearing and in the Related Proceedings), 26 August 2011, International Criminal Court, ICC-01/o902/11 (hereafter Muthaura, Kenyatta \& Ali (Victim Participation at Confirmation Charges Hearing)), paras. 79, 81, 91; Redress, Representing Victims before the Icc: Recommendations on the Legal Representation System (April 2015), p. 6, www.redress.org/wp-content/upload s/2017/12/1504reprentingvictims.pdf, accessed 29 August 2017.

47 Prosecutor v. Katanga and Chui (Order on the organisation of common legal representation of victims), 22 July 2009, International Criminal Court, ICC-01/04-01/07, para. 11; Prosecutor v. Banda and Jerbo (Decision on common legal representation), 25 May 2011, International Criminal Court, ICC-02/05-03/o9 paras. 12-14; Prosecutor v. Ongwen (Decision on contested victims' applications for participation, legal representation of victims and their procedural rights), 27 November 2015, International Criminal Court, ICC-02/0401/15, para. 17; Lubanga (Victims' Participation), supra note 37, para. 123; Prosecutor v. Ruto and Sang (Decision on victims' representation and participation), 3 October 2012, International Criminal Court, ICC-01/o9-01/11 (hereafter Ruto \& Sang (Victim's representation and participation)) para. 24; Prosecutor v. Gbagbo (Decision on Victims' Participation and Victims' Common Legal Representation at the Confirmation of Charges Hearing and in the Related Proceedings), 4 June 2012, International Criminal Court, ICC-02/11-01/11 (hereafter Gbagbo (Victims' participation and representation)), para. 35; Prosecutor v. AlMahdi (Decision on Victim Participation at Trial and on Common Legal Representation of Victims), 8 June 2016, International Criminal Court, ICC-01/12-01/15, para. 36; Prosecutor v. Bemba (Fifth Decision on Victims' Issues Concerning Common Legal Representation of Victims), 16 December 2008, International Criminal Court, ICC-01/05-01/o8, para. 7; Muthaura, Kenyatta \& Ali (Victim Participation at Confirmation Charges Hearing), supra note 46, paras. 78-79; Prosecutor v. Ntaganda (Decision Concerning the Organisation of Common Legal Representation of Victims), 2 December 2013, International Criminal Court, ICC-01/04-02/06, para. 22.

48 Rule 9o(2) ICC RPE.

49 See e.g. Prosecutor v. Muthaura and Kenyatta (Decision on victims' representation and participation), 3 October 2012, International Criminal Court, ICC-01/og-02/11, para. 6o; Gbagbo (Victims' participation and representation), supra note 52, para. 42; Ruto \& Sang (Victim's representation and participation), supra note 52 , para. 44. 
treated victims' views on their legal representation as 'a relevant, but not a determinative nor even a predominant consideration.' ${ }^{50}$ Hence, it seems that for the appointment of a common legal representative, victims' choices do not matter.

Nevertheless, it should be pointed out that the Court has the responsibility to enable victims to choose how they wish to be represented before the Court. ${ }^{51}$ But in practice victims are merely allowed to indicate on the victim's application form whether they agree with a collective legal representative. ${ }^{52}$ Victims thus lack the procedural capacity to bring claims through a representative of their own choice that they feel will represent their personal interests in ICC proceedings. Whether this is a problem may depend the circumstances of each case. Clearly one representative for numerous victims cannot invest as many resources in factual investigation and legal research of each and every victim, which might influence the outcome of the case. Moreover, it is important to keep in mind that victims are individuals with their own specific story, experience and harm..$^{53}$ Collective legal representation (particularly when appointed by the Court) might not do justice to the stories of individual victims and accordingly has the potential of undermining an important goal of victim participation in ICC proceedings, which is to give victims a voice. ${ }^{54}$

Another consequence of collective representation is that it generally leads to cases being pleaded in the absence of the victims. This makes it extremely difficult for victims to assess the fairness of their hearing and feel connected to the proceedings that usually take place on the other side of the world.

5o Human Rights Watch, 2017, supra note 45, p. $5^{2}$.

$5^{1}$ 'The language and structure of rule 90 prioritizes in 9o(1) the right of victims to choose counsel and only where the court decides to organize CLR, 9o(2); it then prioritizes enabling victims to exercise choices as a group over who is to be the CLR. Rule 9o(3) provides that intervention by the court into victims' choices of CLR is conditional upon its prior determination that victims are 'unable to choose'. See Human Rights Watch, supra note 45, p. 4 .

52 Prosecutor v. Ongwen (First Report on Applications to Participate in the Proceedings), 18 September 2015, Registrar of the International Criminal Court, ICC-02/04-01/15, para. 21. Human Rights Watch 2017, supra note 45, pp. 30-37. In what has been an exceptional case, the CORE team in Uganda organised the victims in such a way that they chose a legal representative on the ICC external counsel list. This allowed victims to exercise their right under rule go (1) ICC RPE, becoming the exception to the rule.

53 Suprun, supra note 41, p. 982.

54 Catani, supra note 4, p. 919. 


\subsection{Collective Reparations}

Another manifestation of the Court's collective approach to victims can be found in the ICC's tendency to deal with reparation claims collectively.

Rule 97 of the ICC Rules of Procedure and Evidence stipulates that ' $\mathrm{t}$ ] aking into account the scope and extent of any damage, loss or injury, the Court may award reparations on an individualised basis, or, where it deems it appropriate, on a collective basis or both'. The Court's case-law to date suggests that collective reparations awards will generally be preferred over individual reparations. ${ }^{55}$

An important reason underlying the Court's preference for collective reparations appears to be a practical one. It is said that the sheer number of victims leaves the Court no choice but to adopt a collective approach. ${ }^{56}$ From the perspective of providing victims with a cheap, quick and relatively simple procedure for getting compensation for their losses, collectively goes much faster and does not result in too much additional workload or a significant impact on the conduct of the proceedings and the length of the trials.

In the Lubanga case, the Trial Chamber did not decide on individual applications, instead endorsing a 'community-based approach' to reparations, ${ }^{57}$ which was 'geared towards facilitating swift collective reparation through the Trust Fund'. ${ }^{8}$ Since both groups of victims had argued for individual reparations $^{59}$ this brought disappointment on part of the victims, ${ }^{60}$ prompting the legal representatives of Victims Vo1 and Victims Vo2 to institute separate appeals under Article 82(4) of the Statute. ${ }^{61}$

55 E.L. Camins, 'Needs or Rights? Exploring the Limitations of Individual Reparations for Violations of International Humanitarian Law', 10 International Journal of Transitional Justice (2016) 126-145, p. 142; C. Stahn, 'Reparative Justice after the Lubanga Appeal Judgment: New Prospects for Expressivism and Participatory Justice or "Juridified Victimhood" by Other Means?', 13Journal of International Criminal Justice (2015) 801-813.

56 See also Henzelin et al., supra note 4.

57 Prosecutorv. Lubanga (Decision Establishing the Principles and Procedures to be Applied to Reparations) 7 August 2012, Trial Chamber I, ICC-01/04-01/o6.

58 Stahn, supra note 55 , p. 804.

59 S. Yogendran, 'Did the ICc Fail Child Victims in the Lubanga Reparations Order?', 9 Amsterdam Law Forum (2017) 65-83, p. 66.

6o Stahn, supra note 55, p. 804.

61 Appeal against Trial Chamber I's Decision Establishing the Principles and Procedures to Be Applied to Reparation of 7 August 2012, Lubanga (ICC-01/04-01/06),Vo1 team of legal representatives, 3 September 2012; Appeal against Trial Chamber I's Decision Establishing the Principles and Procedures to be Applied to Reparations of 7 August 2012, Lubanga (ICC-01/04-01/06), Office of Public Counsel for Victims/Vo2 team of legal representatives, 24 August 2012. 
Nevertheless, the Appeals Chamber found that the Trial Chamber did not err in deciding to award reparations only on a collective basis rather than an individual basis, and highlighted that the number of victims is an important factor in determining that reparations on a collective basis are more appropriate. The Chamber emphasized that there is no internationally recognized human right to the consideration of individual applications for reparations. ${ }^{62}$

An important consequence of this collective treatment is that the specific characteristics of individual victims' claims are lost. This goes to show that unlike an accused, a victim rarely has a face, be it even through their representative. He or she is usually referred to as a number and his or her claims do not receive the Court's attention individually. Indeed, in the Lubanga case, the Appeal Chamber observed: 'When only collective reparations are awarded ... a Trial Chamber is not required to rule on the merits of the individual requests for reparations' ${ }^{63}$ Another important reason underlying the Court's preference for collective reparations can be found in the ICC's apparent objective to reach as many victims as possible.

After Lubanga was convicted, the Court's first-ever decision on reparations was issued on 7 August 2012. The Trial Chamber observed that:

In the Chamber's view, reparations, as provided in the Statute and Rules, are to be applied in a broad and flexible manner, allowing the Chamber to approve the widest possible remedies for the violations of the rights of the victims and the means of implementation. ${ }^{64}$

This statement indicates that the Court wishes to bring as many victims as possible under its reparations order. Indeed, the Trial Chamber found that it would be inappropriate to limit reparations to the relatively small group of victims that participated in the Trial and those who applied for reparations.' ${ }^{65}$

The ICc's objective to reach as many victims as possible was confirmed during the reparations proceedings in the Katanga case, when the Trial Chamber

62 Lubanga (Appeals Judgment on Reparations principles), supra note 34, para. 155. See also Prosecutor v. Al Mahdi (Reparation Order), 17 August 2017, International Criminal Court, ICC-01/12-01/15 (hereafter Al Mahdi (Reparation Order)), paras. 141-142.

63 Lubanga (Appeals Judgment on Reparations principles), ibid. See also Al Mahdi (Reparation Order), ibid.

64 Lubanga (Decision on Reparation principles), supra note 40, paras. 179-180.

65 Ibid., para. 187. 
offered additional victims who had not yet come forward the opportunity to participate during the trial to apply for reparations. ${ }^{66}$

In its Appeals Judgment on the Lubanga case, the Appeals Chamber ruled that collective reparations can be awarded irrespective of whether victims submitted a request for reparations and whether they participated in the trial proceedings. ${ }^{67}$ This is because all victims are to be treated fairly and equally as regards to reparations. The Trial Chamber considered:

given the uncertainty as to the number of victims of the crimes in this case - save that a considerable number of people were affected - and the limited number of individuals who have applied for reparations, the Court should ensure there is a collective approach that ensures reparations reach those victims who are currently unidentified. ${ }^{68}$

The Trial Chamber made a similar decision in the AlMahdi case. It decided to set aside the individual applications for reparations because it has received only 139 applications during the reparations phase, despite determining that collective harm was suffered across Timbuktu (a city of approximately 70,000 people around the time of the attack)'. It set aside its own ruling on the applications with an administrative screening by the Trust Fund for Victims. ${ }^{69}$

While the ICC seems to want to include as many victims as possible, the same is not true when it comes to the perpetrators of crimes within its jurisdiction. When dealing with genocide there are a great number of perpetrators. Here the Court has, however, taken measures to limit the number of perpetrators it can potentially try. It aims to 'only' prosecute and try 'the most serious crimes.70 Just as the Court has accepted that it can only try the most serious crimes, it should accept that it cannot reach all victims and focus on maximizing justice to those victims that have brought reparations claims before it. ${ }^{71}$

We know that international criminal courts are not capable of dealing with large numbers of accused. It is left to domestic criminal courts to try the remainder of the culprits. But why then try to include as many victims as

66 Prosecutor v. Katanga, (Decision on the 'Demande de clarification concernant la mise en œuvre de la Règle 94 du Règlement de procédure et de preuve' and future stages of the proceedings), 8 May 2015, International Criminal Court, ICC-01/04-01/07, para. 19.

67 Lubanga (Appeals Judgment on Reparations principles) supra note 34, para. 151.

68 Lubanga (Decision on Reparation principles), supra note 40, para. 219.

69 Al Mahdi (Reparation Order), supra note 62, paras. 141-142.

70 Art. 1 ICCSt; see also Art. 5 ICCSt, "The jurisdiction of the Court shall be limited to the most serious crimes of concern to the international community as a whole'.

71 See Moffett, supra note 5, p. 284. 
possible, with no threshold regarding the damage or injuries that they have suffered? There is apparently a belief that victims' claims can easily be dealt with all together. Does this have to do with the political image of the courts? That their explicit aim is to do justice to the victims? In view of victims' weak legal position at the ICC, I am wondering whether they are being the ICC's tool, or doormat.

The Court's collective approach to reparations once again affirms that, in practice, victims are no more than the target of reparations, they are the recipients. Reparation proceedings before the ICC are not so much concerned with victims' rights and, once again, it can be said that victims are treated as objects as opposed to subjects with agency that can demand legal remedies.

Legal Accountability versus Humanitarian Assistance

Finally, what we are seeing is that rather than applying the legal principle of legal accountability to victims' claims for damage, their compensation is too often approached as a humanitarian or charity effort. The ultimate consequence of this approach is that there is only a weak relation between the claim(s) for reparations and the legal accountability of the convicted person towards one or more victims. As is discussed below, this problem is further enhanced by the role of the Trust Fund for Victims (TFV). Read this observation of the Trial Chamber in Lubanga:

Reparations proceedings and reparations orders and programmes in favour of child soldiers, should guarantee the development of victims' personalities, talent and abilities to the fullest extent and, more broadly, they should ensure the development of respect for human rights and fundamental freedoms ${ }^{\prime 72}$

When I first read this, I thought that this was a social worker or psychologist speaking. I do not need to say that these objectives, the development of victims' personalities, talent and abilities to the fullest extent, are highly respectable and no one could be against them. But that may be exactly the problem. In my view, they do not belong in a court of law. A court of law deals with disagreements between parties, over legal rights and obligations. These need to be weighed and determined. A court of law has to dispense justice, deal with

72 Lubanga (Decision on Reparation principles), supra note 40, para. 213. 
legal disputes between parties and can carry out the administration of justice in accordance with the rule of law.

A complicating factor in this respect is also the Court's efforts to avoid tensions between victims. In Lubanga the Trial Chamber considered that: 'individual reparations should be awarded in a way that avoids creating tensions and divisions within the relevant communities. ${ }^{\prime 3}$ It is a fact that compensation can lead to tensions and divisions. Since the Court is not in a position to deal with all victims (as it is not in a position to deal with all crimes and all perpetrators), there are victims who will be excluded from its reparations orders. But it is debatable whether the Court should consider itself responsible for such tensions. If an individual is legally entitled to reparations, to what extent should the Court take into account community interests? Again, a conception of victims transpires as a large community at the cost of individual entitlements to reparation on the basis of the law and accountability.

The Appeals Chamber's judgment on reparations has drawn reparations more into the legal domain, explicitly grounding the ICC's reparations regime in the principle of accountability of the offender towards victims. ${ }^{74}$ It has been considered that the Appeals Chamber's Order for Reparation 'prioritizes accountability over broader concerns, such as well-being, security or peace. ${ }^{75}$ However, the role afforded to Trust Fund for Victims (TFV) in implementing the reparations awards has blurred the line between legal accountability and humanitarian assistance.

The TFV has been afforded a dual role under the Rome Statute. It is a body through which the Court can make reparation awards, ${ }^{76}$ but it can also independently render assistance for the benefit of victims. ${ }^{77}$ However, it appears that in practice the $\mathrm{TFV}$ is unable to separate these two roles. ${ }^{78}$ In the Luban$g a$ case, for example, the TFV has initiated its collective reparations projects, which include socio-economic development programmes and psychological

73 Ibid., para. 220.

74 Lubanga (Appeals Judgment on Reparations principles), supra note 34, para. 69; Stahn, supra note 55, p. 805; Camins, supra note 55, p. 141.

75 Stahn, supra note 55 , p. 812.

76 Rule 98(3) ICC RPE: 'The Court may order that an award for reparations against a convicted person be made through the Trust Fund where the number of the victims and the scope, forms and modalities of reparations makes a collective award more appropriate'; Art. 75(2) ICCSt 'Where appropriate, the Court may order the award for reparations be made through the Trust Fund provided for in article 79'.

77 C. McCarthy, Reparations and Victim Support in the International Criminal Court (cup, Cambridge, 2012), p. 84 .

78 Yogendran, supra note 59, p. 80. 
and physical rehabilitation, ${ }^{79}$ and has also begun implementing symbolic measures such as mobile memorialization initiatives and commemoration centres. ${ }^{80}$ These measures 'mirror assistance programmes already operated by the TFV', 81 casting doubt on their reparative value for victims. As such, the TFV's role in reparations 'risks diluting victims' "right" to reparation by merging it with assistance.'82

When implementing the Court's reparations orders the TFV tries to be as inclusive as possible. For example, civilians targeted by Lubanga's troops could not be officially recognized as victims because the warlord was only convicted of enlisting and using child soldiers. The director of the TFV argued that this is why those communities should be included in a consultative process on reparations: to prevent reparations awards to victims from leading to 'more harm and jealousy'.83

A sensitive issue in both the Lubanga and Katanga cases is that, due to the specific charges for which these men were convicted, almost all victims are of Hema ethnicity. Other ethnic groups who also suffered as a result of these men's actions have not been formally recognized as victims. 'It is another reason why we prefer to have an approach of designing reparations in which not only victims, but also communities are consulted. To avoid problems that might even reignite the conflict', explains the TFV director. ${ }^{84}$

However, as respectable as these objectives are, they also reveal a tension between the ICC and the TFV. The Court is not the place to go to with the aim to reintegrate ethnic groups or communities. Proponents of a large role of the $\mathrm{TFV}$ in reparation, as well as the TFV itself, clearly value peace over justice. I would argue, however, justice over peace. The ICC is one of the very few institutions out there that can adjudicate. Leave peacebuilding to other bodies.

79 Prosecutor v. Lubanga (Information Regarding Collective Reparations), 31 February 2017, ICC-01/03-01/06-3273.

8o Prosecutor v. Lubanga (Information Regarding Collective Reparations, Annex A: (Draft) Scope of Work, Collecctive Reparations Projects in Relation to the Conviction of Thomas Lubanga Dyilo before the International Criminal Court), 13 February 2017, ICC-01/o3-01/o6-3273-AnxA.

81 Moffett, supra note 3, p. 1208.

82 Ibid., p. 1209.

83 T. Lingsma, 'A Banner Year for Victims' Reparations at the International Criminal Court?' 173 International Justice Tribune (2015), online at <http://www.tjitske-lingsma.nl/wp-con tent/uploads/2013/o2/A-banner-year-for-victims $\% \mathrm{E} 2 \% 80 \%$ 99-reparations-at-the-Inter national-Criminal-Court-International-Justice-Tribune-173.pdf>, accessed 22 December 2017.

84 Ibid. 
The TFV may certainly be helpful as a fund providing assistance to victims, a fund to the 'benefit of victims' ${ }^{85}$ As the Trust Fund is not bound by narrowly defined legal principles, it can be more flexible and is likely better equipped to deal with large number of victims. But this does not entail that the Trust Fund should replace the ICC in the latter's responsibility regarding legal reparations. This is precisely what is happening when the ICC does not rule on individual applications for reparations but leaves the identification of victims and implementation of reparations to the TFV.

In the AlMahdi case, the Trial Chamber considered:

When the Court does not identify the beneficiaries, it falls to the TFV to establish a verification procedure to determine that any persons who identify themselves to the TFV are in fact members of the beneficiary group. The Chamber considers that proceeding in this manner is an alternative to an application-based process, whereby the Chamber assesses the reparation requests of identifiable beneficiaries filed pursuant to Rule 94 of the Rules. ${ }^{86}$

It must be said that in this case, the instructions of the ICC were more specific than in other cases, as the Chamber - while recognising the TFV's 'general position to prioritise collective awards - ordered that the limited number of individual reparations should be prioritised during the implementation', although it immediately downplayed this instruction by adding that the TFV should only do so 'insofar as individual reparations do not hinder broader reconciliation or stigmatise individual victims vis-à-vis the community of Timbuktu' ${ }^{87}$

In practice the ICC relinquishes its competence to rule on individual victims' reparations claims to the TFV. However, the TFV is, more than anything, a humanitarian fund. The work of the TFV does not lead to a public standard setting. Judicial decisions do have that function of standard setting. Decisions of a court of law indicate which actions are considered socially and morally acceptable under the current legal system. ${ }^{88}$ The $\mathrm{TFV}$ cannot have that role.

85 Rule 98(5) ICC RPE.

86 AlMahdi (Reparation Order), supra note 62, para. 143.

87 Ibid., paras. 29 and 140 .

88 R.H. de Bock, De toekomst van de civiele rechtspraak: Een pleidooi om de rechter niet te ontlasten (Uitgeverij Parijs, Zutphen, 2017), p. 14; see for the pros and cons on private dispute settlement, for example, C. Giabardo, 'Private Law in the Age of the "Vanishing Trial", in K. Barker, K. Fairweather and R. Grantham (eds.), Private Law in the 21st Century (Hart Publishing, Oxford, 2017), pp. 547-56o; E. Thornberg, 'Reaping what we sow: anti-litigation rhetoric, limited budgets, and declining support for civil courts', 30(1) Civil 
What is more, the TFV lacks impartial and independent judges to decide on which reparations should be made and how these should be made. By referring victims' claims to the TFV they remain outside of the scope of justice, the rule of law and the public domain. Victims should not be excluded from this domain..$^{89}$

Various international criminal courts deal with victims differently. There has been outright opposition to victims' participation in criminal trials, reluctant acceptance, and apparent embracement. However, even when there seems to be embracement, such as by the ICC, under the surface victims struggle to get their rights and damage recognized.

Compared to the rights of the accused, and the administration of the prosecution, the rights of victims lag far behind. This is understandable to a certain extent. The functioning and the capacity of these tribunals are determined by their objective to try and convict perpetrators of international crimes. Victims are a side matter that these tribunals wish to include in the margins of their functioning. However, this does raise the question whether international criminal courts are the right place of action to meet victims' interests.

The ICC jurisprudence on victims is still developing. The principles on reparations as articulated by the Appeals Chamber in the Lubanga appeal-case have drawn reparations more into the legal domain. Moreover, from the perspective of empowering victims, the ICC ruling in the Katanga case is better than the judgment of the Trial Chamber in Lubanga as reparations were also awarded to individual victims

The problem we currently face is that victims are dealt with merely as persons who have suffered and not as persons that have rights, and should be able to claim their rights. Trials and judgments are necessary. They are painful last resorts, but they are necessary. We have to deal with large-scale traumas and

Justice Quarterly (2011) 74-92; D. Luban, 'Settlements and the Erosion of the Public Realm', 83 Georgetown Law Journal (1995) 2621; O. Fiss, 'Against Settlement', 93(6) Yale Law Journal (1984) 1073-1090; M. Loth and E. Mak, 'The Judicial Domain in View - Figures, Trends and Perspectives', 3(1) Utrecht Law Review (2007) 75-100; H. Genn, Why the Privatisation of Civil Justice is a Rule of Law Issue (36th F.A. Mann Lecture, 2012); H. Genn, Judging Civil Justice, The Hamlyn Lectures 2008 (Cambridge University Press, Cambridge, 2010); The actions reflect morally and socially acceptable behaviour in society judged by the judicial system.

De Bock, supra note 88, p. 16. 
damage that are at the basis of the existence of international criminal courts. We need standard setting and law-making, not mere humanitarian aid or a kind of settlement approach. That means that we need trials that deal with the question of reparations, based on the legal principle of accountability. ${ }^{90}$ This may lead us to think beyond the current organisation of the ICC and force us to start thinking about setting up a victims' claims chamber at the ICC with specialized judges.

9o Luban, supra note 88, pp. 2621-2622. 